\title{
Social Status, Inflation and Endogenous Growth in a Cash-in-Advance Economy: A Reconsideration Using the Credit Channel*
}

\author{
Rangan Gupta and Lardo Stander \\ University of Pretoria
}

\begin{abstract}
Conventional models of social status purport a positive inflationgrowth relationship, and attribute this empirical contradiction to the presence of a consumer's desire for social status. These models are dominated by a substitution effect of money holdings for capital holdings, as an increase in the inflation rate due to money growth raises the cost of holding money and depresses the real money holdings. Using a monetary endogenous growth model, the effects of wealth-induced social status on long-run growth is reconsidered. The analysis is enhanced through the addition of a competitive banking sector that intermediates the available capital in the economy, subject to a mandatory cash reserve requirement. The cash reserve requirement creates a wedge between the deposit rate and the loan rate. While the real loan rate is tied with the constant marginal product of capital, the real deposit rate is negatively related to the rate of inflation. This leads to another, opposing substitution effect of deposit holdings for real money holdings and hence, increases the cost of holding deposits as inflation increases. The consolidated theoretical model described herein supports a diverse range of theoretical findings, contingent on the presence of wealth effects or the spirit of capitalism, using a simpler and more tractable framework that accounts for the role of the banking system in monetary policy decision outcomes. Significantly, as long as the mandatory reserve requirement imposed on the banking system by the monetary authority exceeds a (small) critical value, an increase in the money growth rate will lead to a decrease in the long-run growth rate of the economy.
\end{abstract}

${ }^{*}$ We would like to thank two anonymous referees for many helpful comments. However, any remaining errors are solely ours. 
JEL Classification: E58, O42, P16

Keywords: Social status, reserve requirements, monetary model with endogenous growth, cash-in-advance. 


\section{Introduction}

"In order to hold the esteem of men, it is not sufficient merely to possess wealth or power. The wealth and power must be put in evidence, for esteem is awarded only on evidence." - Thorstein Veblen (1899)

The effect of monetary growth - and hence, the efficiency or optimality of monetary policy - on capital accumulation and economic growth remains a central theme in macroeconomic literature. In the aftermath of the 2007-2009 financial crises, renewed theoretical focus has characterised the global monetary policy environment. ${ }^{1}$ Complementary to this broader debate, there is also a deepening in the literature studying the effects of wealth-induced preferences for social status (or "the spirit of capitalism" of Weber (1905)) on capital accumulation and economic growth using dynamic general equilibrium (DGE) models. Chang, Hsieh and Lai (2000) amends the framework of Stockman (1981) and establishes a one-sector monetary growth model where the production function takes the general AK form as the engine of growth and a cash-in-advance (CIA) constraint applies to consumption only. The results from the Chang et al. (2000) model seem to confirm the well-known Mundell (1963) and Tobin (1965) effect, ${ }^{2}$ namely that an increase in the money growth rate leads to an increase in the longrun growth rate of the economy, if a capital stock due to a wealth motive is included directly in the production function. This would imply that consumers derive utility not only from consumption, but also from holding capital stock based on a direct wealth motive as some "evidence of esteem" (Veblen, 1899). ${ }^{3}$ Further proof that individuals care about their social status in a market economy and pursue capital accumulation to advertise their wealth to achieve social status and power is provided by Zou (1994), Bakshi and Chen (1996), Corneo and Jeanne (1997) and Futagami and Shibata (1998).

Using Chang et al. (2000) as a benchmark, subsequent studies on Kurz's

\footnotetext{
${ }^{1}$ See the notable contributions of Blanchard, Romer, Spence and Stiglitz (2012), Sims (2012) and Friedman (2013), among others.

${ }^{2}$ These results, however sharply contradict the super-neutrality of money proposition of Sidrauski (1967).

${ }^{3}$ The holding of capital stock for wealth solely due to its inferred social status, and not for financing future consumption, is a notion that has been well developed by Smith (1776), Veblen (1899), Weber (1905), Keynes (1920) and mathematically by Kurz (1968).
} 
(1968) wealth effects, or linking an individual's preference for capital holding with wealth and social status, produced mixed and ambiguous results. Zou (1998) included money directly in the utility function (MIU) in a one-sector model and found that higher inflation leads to higher capital stock in the long run, thus increasing the endogenous growth rate of the economy. Gong and Zou (2001) finds the same result with a similar model, but using a CIA constraint on consumption only, instead of a MIU specification. When the liquidity constraint is applied to both consumption and investment, the results are ambiguous and depend on the weight ascribed to social status in the utility function and investment in the CIA constraint. Chang and Tsai (2003), using the exact framework of Gong and Zou (2001), finds the exact opposite result. More recently, Chen and Guo (2009) with a similar framework but with the CIA constraint applying to both consumption and investment, present results that inflation is detrimental to economic growth. ${ }^{4}$

To gain an understanding of the Chang et al. (2000) results, consider intuitively the presence of an individual's preferences for social status under a binding CIA constraint: an increase in the money growth rate leads to an increase in inflation, which in turn increases the opportunity cost of consuming as consumption purchases requires the individual to keep cash to effect such purchases. The individual will thus substitute consumption goods for capital goods, and given the social status motive this substitution will lead to higher capital accumulation. In the endogenous growth framework, the mechanism is slightly different: an increase in the money growth rate causes inflation, which in turn leads to a decrease in the holding of real money balances and thus to a decrease in consumption (as consumption require cash in advance). The individual will thus substitute towards physical capital, as the real rate of return on physical capital is constant. As capital accumulation promotes higher social status and the individual's social status matters, he has a further incentive to accumulate capital. As long as there are constant returns to scale (CRS) with respect to capital, the growth rate of the economy will increase due to increasing capital accumulation.

\footnotetext{
${ }^{4}$ There are also studies that examine the money growth rate effect on the economy within a two-sector framework characterized by social status (see for example Chang et al. (2008), and Chen (2011)). These studies show that when social status is represented by capital, and the CIA constraint applies to both consumption and investment with a generalized human capital formation process (i.e., the process includes physical capital, besides human capital), money growth rate negatively impacts economic growth rate.
} 
This intuitive explanation and the results presented by Chang et al. (2000), present an impasse in that a positive growth-inflation relationship is inconsistent with the empirical evidence on the growth-inflation phenomenon and is even inconsistent with the literature on threshold inflation as more clearly detailed in Vaona and Schiavo (2007), Jha and Dang (2012) as well as Neanidis and Savva (2013). ${ }^{5}$

We provide a novel and simple explanation of the effects of monetary growth on economic growth that is empirically consistent. Benchmarking the Chang et al. (2000) framework, we reconsider the monetary growth impact by introducing a competitive banking sector subject to mandatory reserve requirements along the lines of Chari et al. (1995). Note that, Chari et al. (1995) attempted to match the size of the effect of inflation and growth as reported in empirical studies, with those obtained from endogenous growth models with and without banking intermediation. However, they are unable to match the size of the impact reported in econometric model, to the extent that the growth rate of the money supply is found to have a quantitatively trivial effect on the growth rate of output. The incorporation of the banking sector into a monetary model of social status with endogenous growth allows the banking system to play a fundamental role in facilitating both production and capital accumulation and hence, long run economic growth.

To our knowledge, the model presented here is the first attempt at explaining how the money growth rate together with cash reserve requirements - in a similar vein as the reserve requirement coordinating arrangement proposed by Barnett (2005) - affect the outcome of an endogenous monetary model in the presence of the spirit of capitalism or wealth-induced social status. More specifically, the paper brings the importance of the banking literature, especially cash reserve requirements, to bear upon the inflationgrowth relationship, which in the presence of social status in an endogenous growth model was found to be positive and hence, inconsistent with the empirical literature. In other words, through the explicit modelling of the banking sector in an otherwise standard endogenous growth model with spirit of capitalism, we are able to obtain the empirically consistent negative relationship between growth and inflation under certain very plausible

\footnotetext{
${ }^{5}$ See Bittencourt (2011), Berentsen, Breu and Shi (2012) and most recently Barro (2013) for more detail on the negative growth-inflation relationship.
} 
conditions on the cash reserve requirements.

Cash reserve requirements have long been perceived as a measure of financial repression, since higher cash reserve requirements result in fewer loans available to a bank to lend out for investment/production purposes. For a detailed discussion along these lines, refer to Gupta (2008), Gupta and Ziramba $(2009,2010)$ and Bittencourt, Gupta and Stander (2014). Essentially, the cash reserve requirement induces a wedge between the deposit rate and the loan rate and hence, creates friction in financial intermediation (Haslag and Young, 1998). Although the mandatory reserve requirement ratios have been reduced consistently across developed and developing countries (Di Giorgio, 1999), it is still considered a monetary policy instrument that broadens the inflation tax base (as it increases real money balances for a given level of deposits in the banking system) and it is still widely used as a liquidity management tool making it easier for central banks to influence the level of market interest rates, as clearly explained in Primus (2013).

Moreover, Chari et al. (1995) report a reserve requirement ratio for the United States (US) over the period 1986-1991 of 4.2 percent. Di Giorgio (1999) summarises data on the reserve requirement for a host of industrial countries over the period 1990-1996 and reports a range of values between 0.5 percent to 22.5 percent, and recently Gupta (2011) reported the average reserve requirement value for a large number of countries to be 22.0 percent. Lastly, Carrera (2013) reports that only 9 of the central banks recently surveyed had a 0 percent reserve ratio; 51 had a reserve ratio between 6 percent to 15 percent, and 15 had a reserve ratio of more than 16 percent. Clearly, reserve requirements are widely prevalent and at times quite significant in size, and hence, cannot be ignored as a monetary policy instrument.

There are two opposing effects on long-run growth in the presence of social status when banks face cash reserve requirements, given an increase in the growth rate of money. One is the well-known Tobin (1965) portfolio substitution effect, where the resultant increase in inflation due to an increase in the money growth rate leads to substituting real balances for capital, as the marginal product of capital is constant and not affected by cash reserve requirements. The resultant increase in capital holdings has a positive effect on long-run growth. This portfolio substitution effect to capital is further reinforced by the preference for social status. The second effect is observed through a deposit rate channel, since the real deposit rate is negatively af- 
fected by inflation, even though the real loan rate is still tied to the constant marginal product of capital (given that we consider an endogenous growth framework).

The disconnect between the real deposit rate and the real loan rate arises because of the cash reserve requirements, which, in equilibrium, create a wedge between the deposit and the loan rates. Hence, a lower real rate of deposits results in agents substituting away from capital goods to holding real balances to finance current consumption. The resultant decrease in capital holdings has a negative effect on long-run growth. But these two effects do not simply cancel each other out and lead to money being superneutral, as in Sidrauski (1967). Our theoretical results show that as long as the cash reserve requirement exceeds a (small) critical value, the effect of inflation or monetary growth on economic growth, is negative. This is in contrast to those findings presented by Chang et al. (2000).

The rest of this paper is organised as follows: Section 2-4, respectively, defines and solves the specific model, characterises equilibrium along a balanced growth path (BGP) and examines the money growth effects within the characterised economy. Section 5 offers some concluding remarks.

\section{The model}

The principal economic activities are: (i) consumers receive income from their deposits held by banks, and do not accumulate capital directly. They also receive lump-sum transfers from the government. Consumers must decide on their consumption, which is financed by cash as well as the deposits they accumulate with due regard to their social status preferences; (ii) firms derive income using a simple AK-type production technology, and accumulate capital by financing capital purchases with loans obtained from banks. Firms choose the amount of capital they purchase as well as the amount of loans they take from the bank; (iii) the banks operate in a competitive environment and perform a rudimentary pooling function by collecting the deposits from the consumers and lending it out to the firms after meeting an obligatory cash reserve requirement. Banks collect the interest rate on these loans and meet their obligation to the depositors; and (iv) there is an infinitely-lived government which supplies money and distributes the seigniorage income in the form of lump-sum transfers to the consumers. 
There is a continuum of each type of economic agent with unit mass.

\subsection{Consumers}

The consumer is an infinitely-lived, representative agent with unit mass who supplies labour inelastically, and hence labour is normalised to unity and there is no labour-leisure decision affecting consumers. The perfect foresight consumer derives utility from both consumption and wealth-induced social status, where social status is represented by his deposits. The idea of direct utility accruing to the consumer from holding capital stock in general, and in this model specifically, deposits, was mathematically formulated by Kurz (1968). The consumer wishes to maximize his intertemporal discounted lifetime utility, where the chosen logarithmic utility function is separable and defined over both consumption and deposits. Formally, the consumer wants to:

$$
\max \int_{0}^{\infty} U(c, d) e^{-\rho t} \mathrm{~d} t
$$

subject to:

$$
\begin{aligned}
& \dot{m_{1}}=r_{d} d+\tau-c-\pi m_{1}-\dot{d} \\
& m_{1} \geq c
\end{aligned}
$$

where $c$ is real consumption and $d$ is real deposits. $m_{1}$ is real money holdings or cash balances held by the consumer to finance consumption; $\tau$ is the real lump-sum transfer received from the government; $\pi$ is the inflation rate, $0<\rho<1$ is the constant time discount rate and $r_{d}$ is the net real rate of return on the consumer's deposits. A dot over the variable denotes the time derivative. Following Chang et al. (2000), we specify: $U(c, d)=$ $[\log (c)+\beta \log (d)]$ with $\beta \geq 0$ being the degree of the consumer's preference or desire for social status. Both utility functions for consumption and deposits in (1) are well-behaved, i.e., are characterized by increasing marginal utilities at a decreasing rate. (2) and (3) are the consumer's budget constraint and the cash-in-advance (CIA) constraint for consumption goods, respectively. The consumer's current value Hamiltonian is specified as:

$$
H_{c}=\log (c)+\beta \log (d)+\lambda\left[r_{d} d+\tau-c-\pi m_{1}-\dot{d}\right]+q\left[m_{1}-c\right]
$$


where $\lambda$, the shadow price of real money balances and $q$, the Lagrange multiplier for the CIA constraint in (3), which is assumed to be strictly binding in equilibrium, ${ }^{6}$ are the co-state variables (or the multipliers of $H_{c}$ ) and the optimum conditions necessary for the consumer are given by the respective first-order conditions of: ${ }^{7}$

$$
\begin{aligned}
c & : \frac{1}{c}=\lambda+q \\
m_{1} & :-\lambda \pi+q=\rho \lambda-\dot{\lambda} \\
d & : \frac{\beta}{d}+\lambda r_{d}=\rho \lambda-\dot{\lambda}
\end{aligned}
$$

where (5) equates the marginal benefit and marginal cost of consumption; (6) states that the marginal value of real money holdings is equal to its marginal cost and (7) determines the evolution of real deposits over time, where $\frac{\beta}{d}$ is the marginal benefit of accumulating deposits. Note that in the presence of a desire for social status, thus when $\beta>0$, the marginal benefit of accumulating deposits increases.

\subsection{Banks}

As in Chari et al. (1995), there exist a finite number of banks in this economy, which we assume to behave competitively and who are all subject to an obligatory cash reserve requirement $\gamma$, set by the government. Two simplifying assumptions, that no resources are used to operate the banking system and bank deposits are essentially one period contracts, guarantee that all competitive banks levy the same cost on their loans, the nominal loan rate $i_{l}$ and guarantee the depositor a nominal deposit rate, $i_{d}$. Banks accept and pool deposits, choose their allocation portfolio of loans and required cash reserves and then extend loans to firms, subject to $\gamma$, with the goal of maximising their profits. Subsequently, banks receive interest income from loans to firms and meet their interest obligations to depositors. The bank's balance sheet is constrained by the reserve requirement, and is represented

\footnotetext{
${ }^{6}$ This is a standard assumption in the CIA literature, but more fully explained in Stockman (1981).

${ }^{7}$ Optimisation solutions for the different economic agents are fully set out in the Appendix.
} 
by $(1-\gamma) d=l$. Hence, all banks attempt to:

$$
\max \Pi_{B}=\left[\left(i_{l}\right) l-\left(i_{d}\right) d\right]
$$

subject to:

$$
\begin{aligned}
m_{2}+l & \geq d \\
m_{2} & \geq \gamma d
\end{aligned}
$$

where $\Pi_{B}$ is the bank's profit function; $m_{2}$ is real money holdings by the banks to meet the reserve requirement, $\gamma$ is the reserve requirement ratio, and $l$ are loans in real terms. (9) is the feasibility constraint (i.e., the bank's balance sheet) and (10) is the bank's reserve requirement constraint. A competitive banking sector is characterised by free entry, which drives profits to zero. Thus, given that (9) and (10) binds, the solution to the bank's problem yields:

$$
i_{l}=\frac{i_{d}}{1-\gamma}
$$

(11) clearly shows that cash reserve requirements lead to a distortion in financial intermediation. Since fiat money, $m_{2}$ has a rate of return dominated by returns on loans, (10) will be binding as banks will hold just enough real money balances to satisfy the legal reserve requirements. Note that we could have easily presented the bank's feasibility condition $((9))$ as an equality, which is what it would be given the bank's profit motive, which would imply that the bank would loan out the entire amount of the deposits after having exactly met the cash-reserve requirement.

The presentation of the constraint as an inequality is to keep the problem structure general, and to indicate that the equality holds only under equilibrium. This helps us avoid imposing the equilibrium condition before solving the optimization problem.

Once we know that the cash reserve requirement is binding, i.e. the banks will only hold reserves up to the point that the requirement is satisfied, it also implies that we could have presented the feasibility condition as equality. The bank's portfolio choice must include both cash reserves and loans, but since reserves do not earn a nominal interest, the real rate of return on deposits is negatively affected by inflation. The size of this effect, or the size 
of the inflation tax on cash reserves, is $-\gamma \pi$. Hence, in equilibrium, the real rate of return on deposits is given by:

$$
r_{d}=(1-\gamma) r_{l}-\gamma \pi
$$

with $r_{d}$ and $r_{l}$ the net real deposit and net real loan rate, respectively.

\section{$2.3 \quad$ Firms}

Firms use only capital $k$ in order to produce the consumption-investment good $y$ with the technology specified by

$$
y=A k, \quad \text { with } \quad A>0
$$

where $\mathrm{A}$ is the constant marginal product of capital, and firms face the following profit $\left(\Pi_{F}\right)$ maximisation problem:

$$
\max \Pi_{F}=\int_{0}^{\infty}\left[P y+P \dot{l}-\left(i_{l}-\frac{\dot{P}}{P}\right) P l-P \dot{k}\right] e^{-r t} \mathrm{~d} t
$$

subject to:

$$
P \dot{k} \leq P \dot{l}
$$

where $i$ are new loans that firms take up from banks; $l$ are real bank loans already received; $\dot{k}$ is the purchase of new capital that firms use in the production and $r$ is the firms' discount rate. It should be clear from (15) that firms are finance-constrained, in the sense that new capital can only be purchased and accumulated by taking up new loans from the banks.

Moreover, since deposits are one-period contracts, loans are also strictly one-period contracts. Chari et al. (1995) shows that with a binding financing constraint as in (15), the choice of $r$ becomes irrelevant and hence the firm's problem reduces to a static one. A simplifying assumption that capital does not depreciate, or that $\delta=0$, does not qualitatively change the results. Since firms rent capital only from the bank, ${ }^{8}$ they will rent capital up to that point where the real rental rate of capital (or the real loan rate of the bank) equals the marginal product of capital. So, in equilibrium, the

\footnotetext{
${ }^{8} \mathrm{~A}$ portion of the capital can be rented by the firm directly from the depositor, as in Chari et al. (1995) and Basu (2001).
} 
solution to the firms problem is simply given by the expression for the real rental rate:

$$
\left(i_{l}-\pi\right)=A \text {. }
$$

So effectively, unlike in the textbook exposition where firm's borrow directly from the household up to the point where the real rate of return on capital is equal to the marginal product of capital, here, with the firms borrowing from the bank, the marginal product of capital equals the real loan rate.

\subsection{Government}

There is an infinitely-lived government which keeps a constant money growth rate $\mu$ and redistributes the collected seigniorage, $\tau$ to the consumers as lump-sum transfer payments. Hence, the government's budget constraint is given as:

$$
g=\tau=\mu m
$$

where

$$
m=m_{1}+m_{2}
$$

By definition, the law of motion applicable to real cash balances is

$$
\frac{\dot{m}}{m}=\mu-\pi \text {. }
$$

The treatment of government in this model is in the vein of Stockman (1981), Wang and Yip (1992), Chang et al. (2000) and more recently, Hosoya (2012).

\section{Equilibrium along a balanced growth path}

Similar to Chang et al. (2000) and Chen and Guo (2009), we focus on the economy's balanced growth path (BGP) along which output, consumption, deposits and real money balances all grow at a common positive rate. A BGP competitive equilibrium for the characterised economy is defined as a sequence of prices $\left\{i_{l}, i_{d}\right\}$, allocations $\{c, \beta, \rho\}$, stock of financial assets 
$\left\{d, m_{1}, m_{2}, k\right\}$ as well as policy variables $\{\tau, \gamma, \mu, g\}$ such that:

- Given $\tau, \gamma, \rho, i_{d}$ and $i_{l}$ the depositor optimally chooses $\beta, c$ and $d$ such that (2) and (3) holds;

- Banks maximise profits subject to $i_{l}, i_{d}$ and $\gamma$ such that (12) holds;

- The equilibrium money market conditions, $m_{1}=c$ and $m_{2}=\gamma d$ hold;

- The loanable funds market equilibrium condition, $i_{l}=\frac{i_{d}}{(1-\gamma)}$ given the total supply of loans $l=(1-\gamma) d$, holds;

- The equilibrium goods market resource constraint, $y=c+i$ holds, where $i=(1-\gamma) \dot{d}$ and $y=A k$;

- The government budget constraint in (17) is balanced on a period-byperiod basis;

- and $d, m_{1}, m_{2}, i_{l}, i_{d}$ and $A$ are positive.

From (5)-(7), ${ }^{9}$ the endogenous inflation rate in this economy is given by:

$$
\pi=\frac{1}{c \lambda}-\frac{\beta}{d \lambda}-\left(1+r_{d}\right)
$$

Now, updating (6) with the explicit value of $\pi$ in (20), we can write the evolution of the shadow price of real money balances as:

$$
-\frac{\dot{\lambda}}{\lambda}=\frac{\beta}{d \lambda}+\left(r_{d}-\rho\right)
$$

Substituting (20) into (19), together with the binding CIA constraint from (3) expressed as $m_{1}=c$, we rewrite the evolution of real money balances as:

$$
\frac{\dot{m}}{m}=\mu-\frac{1}{m_{1} \lambda}+\frac{\beta}{d \lambda}+\left(1+r_{d}\right)
$$

Additionally, from the equilibrium condition for the goods market ${ }^{10}$ and the

\footnotetext{
${ }^{9}$ See Appendix for detail on the BGP solutions.

${ }^{10}$ The standard goods market condition is given by $c+i=y$, but in this economy $i=(1-\gamma) \dot{d}$ results from the fact that $\dot{k}=(1-\gamma) \dot{d}$.
} 
binding CIA constraint $m_{1}=c$, we have:

$$
\frac{\dot{d}}{d}=A-\frac{m_{1}}{(1-\gamma) d}
$$

These expressions in (21)-(23) represent the set of dynamic equations with respect to $\lambda, m_{1}$ and $d$ in our cash-in-advance economy.

Along a BGP, the growth rates of the shadow price, real money balances and deposits must be equal to the economy-wide steady-state growth rate, $g^{*}$ and formally,

$$
-\frac{\dot{\lambda}}{\lambda}=\frac{\dot{m}}{m}=\frac{\dot{d}}{d}=g^{*} .
$$

Hence, from (21)-(24) we derive an explicit relation for the steady-state growth rate of this CIA, monetary endogenous growth economy characterised by wealth-induced social status preferences of consumers:

$$
g^{*}=A-\frac{\rho+\gamma \mu}{(1-\gamma)[1+\beta(1+\mu+\rho)]} .
$$

The result in (25) shows that in this economy, the steady-state growth rate depends on both the monetary policy instruments $\mu$ and $\gamma$, as well as the desire of consumers for social status, $\beta$. This is an extended, but similar result to the one found in Chang et al. (2000).

\section{Equilibrium analysis of money growth effects}

As we are interested in the effects of monetary growth on the characterised economy, we have a set of possible growth outcomes that depends crucially on the parameter specification of the model. To examine the effect of monetary growth on the growth rate of the economy, we take the derivative of $g^{*}$ with respect to $\mu$, resulting in:

$$
\frac{\delta g^{*}}{\delta \mu}=\frac{\beta(\rho+\gamma \mu)-\gamma[1+\beta(1+\mu+\rho)]}{(1-\gamma)[1+\beta(1+\mu+\rho)]^{2}} .
$$

Next, we examine the complete set of four possible steady-state growth outcomes given monetary growth with respect to the parameters of interest in the model. 
Case $1: \beta=0 ; \gamma=0$ :

When there are no wealth-induced social status preferences or cash reserve requirements in the economy, (25) reduces to $g^{*}=A-\rho$. This is the same result, presented in Barro (1990) and Rebelo (1991), found in standard real economy AK-models and for $g^{*}>0$, the assumption that $A>\rho$ or that the marginal product of capital must exceed the constant discount rate of consumers, must hold. More importantly, this result mimics the superneutrality of money proposed in Sidrauski (1967) and further evidenced in Stockman (1981) and Abel (1985). Case 1 clearly implies that the long-run growth of the economy is completely independent of the money growth rate. Intuitively, this is the case because in the absence of the reserve-requirement, the nominal, and hence real, interest rates on loan and deposits are equal to each other. With the real interest rate on loans and thus, deposits, being equal to the constant marginal product of capital $(A)$, the equilibrium growth rate is independent of inflation. In other words, higher money growth rate, resulting in an increase in inflation, would keep the growth rate unaffected as the real rate of return on deposits (and loans) is independent of inflation.

Case $2: \beta \neq 0 ; \gamma=0$ :

When wealth-induced social status preferences exist and consumers derive direct utility from not only consumption but also holding deposits for the sake of advertising their wealth, but there are no frictions in financial intermediation in the economy, (25) reduces to $g^{*}=A-\frac{\rho}{1+\beta(1+\mu+\rho)}$ and the relevant derivative becomes $\frac{\delta g^{*}}{\delta \mu}=\frac{\beta \rho}{[1+\beta(1+\mu+\rho)]^{2}}$, which is the Chang et al. (2000) result. As $\beta \geq 0$, or as long as there are social status preferences present in this economy, $\frac{\delta g^{*}}{\delta \mu} \geq 0$. This is due to a permanent increase in the growth rate of money, depressing real cash balances and by extension, consumption. A higher rate of money growth also increases the inflation rate, which raises the cost of holding money in advance, while the rate of return on capital is constant. Exaggerated by the spirit of capitalism, this provides incentive for the consumer to hold more deposits. Case 2 then confirms the Chang et al. (2000) findings and even the Mundell-Tobin effect, that any positive monetary growth will induce long-run growth.

Case $3: \beta=0 ; \gamma \neq 0$ :

When there are no wealth-induced social status preferences and consumers do not derive any direct utility from holding deposits other than 
for future consumption, but there are cash reserve requirements constraints in the economy, (25) is given by $g^{*}=A-\frac{\rho+\gamma \mu}{(1-\gamma)}$ and the relevant derivative is $\frac{\delta g^{*}}{\delta \mu}=-\frac{\gamma}{(1-\gamma)}$. As $\gamma>0$, it must be that $\frac{\delta g^{*}}{\delta \mu}<0$ and thus, any positive monetary growth will negatively effect long-run growth. The effect is observed through a deposit rate channel, since the real deposit rate is negatively affected by inflation, even though the real loan rate is still tied to the constant marginal product of capital. The disconnect between the real deposit rate and the real loan rate arises because of the cash reserve requirements, which, in equilibrium, creates a wedge between the deposit and the loan rates. Hence, due to a lower real rate of deposits following from higher inflation (due to higher money growth rate), agents substitute away from capital goods to holding real balances to finance current consumption. The resultant decrease in capital holdings has a negative effect on long-run growth.

Case $4: \beta \neq 0 ; \gamma \neq 0$ :

When the economy is characterised by wealth-induced social status preferences and consumers derive direct utility from holding deposits, and simultaneously there is a competitive banking sector subject to a mandatory cash reserve requirement, both (25) and (26) hold as the equilibrium outcome of the economy. Given an increase in the monetary growth rate $\mu$, the reserve requirement leads to a second, opposing effect in the presence of social status. The first effect results in substituting real money balances for capital goods as the cash-in-advance cost increases, and the desire for social status provides further incentive to hold more deposits that yields higher utility. The opposing effect is through a lower real rate on deposits, where $\mu$ negatively effects the real deposit rate. This results in substituting away from holding deposits to holding more real cash balances, besides the need to hold money to finance consumption. However, the main innovation is that the resultant steady-state growth rate being positive or negative, given positive monetary growth, is contingent on the size of $\gamma$. Using (26), we derive an explicit inequality for $\gamma$, which then fully determines the outcome of long-run growth in equilibrium:

$$
\frac{\delta g^{*}}{\delta \mu} \lesseqgtr 0 \quad \text { if } \quad \gamma \gtreqless \frac{\beta \rho}{1+\beta(1+\rho)}=\gamma^{*} .
$$


This implies that as long as the reserve requirement, $\gamma$ exceeds a critical value, $\frac{\beta \rho}{1+\beta(1+\rho)}$ the relationship between the growth rate of the economy and the money growth rate, is negative. Note that, the critical value of $\gamma$ is positively related to $\beta$ and $\rho$, and that $\gamma^{*}<\rho$, which is of the order of 0.01-0.03, which immediately gives an idea about the order of magnitude of $\gamma^{*}$ (numerically suggested below).

To gain some understanding of what this critical value could be, we provide a numerical analysis using a range of parametrisation values observed in Chen and Guo (2011) and Chen (2012) from the social status literature as well as in Karnizova (2010), respectively. The numerical values for $\beta$ are 1; $0.8-1.2 ; 0.83$ and for $\rho$ are $0.03 ; 0.025 ; 0.016$, respectively. The critical values for $\gamma$ can then be calculated and is given by $\gamma^{*}=0.0148 ; 0.011-0.0135$; 0.007. Moreover, when compared to current cash reserve ratios as detailed earlier, it is evident that the critical value(s) that $\gamma$ must exceed are small and within the range when compared to those reserve requirement ratios typically applied by monetary authorities. Hence, the condition required for positive monetary growth to negatively effect the steady-state growth rate, is both plausible and easily met.

\section{Concluding remarks}

Traditionally, monetary models that include the desire for social status and that face a CIA constraint on consumption, have uphold the empiricallyinconsistent Mundell-Tobin finding that a positive monetary growth rate leads to positive long-run growth. These findings are demonstrated through stimulated capital accumulation that is observed due to higher inflation that depresses real money holdings and raises the cash-in-advance cost, and also further enhanced through the individual's preference for social status that provides incentive towards accumulating more capital.

However, we develop a monetary endogenous growth model with a CIA constraint on consumption, characterised by consumer preference for wealthinducing social status and financial repression through a mandatory reserve requirement that is empirically consistent with the international evidence on the negative growth-inflation relationship. Besides the usual substitution effect of real money balances for capital goods (here consisting of deposits) arising from an increase in the inflation rate and an increase in the cost of 
holding money, there is a second, opposing effect necessitated by a decrease in the real deposit rate caused by the disconnect between the loan rate and the deposit rate due to the cash reserve requirement.

The cash reserve requirement distorts the optimal working of the financial market in that deposits can not be fully converted into loans, and hence drives a wedge between the nominal loan rate and the nominal deposit rate in equilibrium. While the real loan rate is tied to the constant marginal product of capital, the real deposit rate is now negatively related to the rate of inflation. So higher inflation resulting from a higher money growth rate lowers real rate on deposits, and since the consumer derives direct utility from holding deposits due to wealth-induced social status, there is an opposite substitution effect away from holding deposits to holding real money balances.

Importantly, following a simpler approach than what is used in the current literature, the model is able to concomitantly account for the Sidrauski effect, the Mundell-Tobin effect and the empirically observed negative growthinflation relationship, contingent on the consumer deriving direct utility from social status and a mandatory reserve requirement imposed on banks. The popular empirical literature result of a negative growth-inflation relationship hinges on the cash reserve requirement exceeding a (small) critical value, the size of which is determined by the weight of the consumer's desire for social status and the constant time discount rate. 


\section{References}

Abel, A. B.: 1985, Dynamic behavior of capital accumulation in a cash-inadvance model, Journal of Monetary Economics 16(1), 55-71.

Bakshi, G. S. and Chen, Z.: 1996, The spirit of capitalism and stock-market prices, American Economic Review 86, 133-157.

Barnett, R. C.: 2005, Coordinating macroeconomic policy in a simple AK growth model, Journal of Macroeconomics 27, 621-647.

Barro, R. J.: 1990, Government spending in a simple model of endogenous growth, Journal of Political Economy 98, 103-25.

Barro, R. J.: 2013, Inflation and economic growth, Annals of Economics and Finance 14(1), 85-109.

Basu, P.: 2001, Reserve ratio, seigniorage and growth, Journal of Macroeconomics 23(3), 397-416.

Berentsen, A., Breu, M. R. and Shi, S.: 2012, Liquidity, innovation and growth, Journal of Monetary Economics 59(8), 721-737.

Bittencourt, M.: 2011, Inflation and financial development: Evidence from Brazil, Economic Modelling 28(1-2), 91-99.

Bittencourt, M., Gupta, R. and Stander, L.: 2014, Tax evasion, financial development and inflation: Theory and empirical evidence, Journal of Banking and Finance 41, 194-208.

Blanchard, O. J., Romer, D., Spence, M. and Stiglitz., J. E.: 2012, In the Wake of the Crisis: Leading Economists Reassess Economic Policy, MIT Press.

Carrera, C.: 2013, The evolving role of reserve requirements in monetary policy, JCC: The Business and Economics Research Journal 6(1), 11-25.

Chang, W.-Y., Chen, Y.-A. and Kao, M.-R.: 2008, Social status, education and government spending in a two-sector model of endogenous growth, The Japanese Economic Review 59(1), 99-112. 
Chang, W.-Y., Hsieh, Y.-N. and Lai, C.-C.: 2000, Social status, inflation, and endogenous growth in a cash-in-advance economy, European Journal of Political Economy 16, 535-545.

Chang, W.-Y. and Tsai, H.-F.: 2003, Money, social status, and capital accumulation in a cash-in-advance model: A comment, Journal of Money, Credit and Banking 35(4), 657-661.

Chari, V. V., Jones, L. E. and Manuelli, R. E.: 1995, The growth effects of monetary policy, Quarterly Review 19(4), 18-32. Federal Reserve Bank of Minneapolis.

Chen, H.-J.: 2011, Social status and long-run effects of monetary policy in a two-sector monetary economy of endogenous growth, Mathematical Social Sciences 61, 71-79.

Chen, H.-J.: 2012, Social status, human capital formation and the long-run effects of money, Journal of Economics 105, 225-246.

Chen, H.-J. and Guo, J.-T.: 2009, Social status and the growth effect of money, The Japanese Economic Review 60(1), 133-141.

Chen, H.-J. and Guo, J.-T.: 2011, Money, social status and endogenous growth in a generalized cash-in-advance model, Pacific Economic Review 16(3), 267-284.

Corneo, G. and Jeanne, O.: 1997, On relative wealth effects and the optimality of growth, Economics Letters 54, 87-92.

Di Giorgio, G.: 1999, Financial development and reserve requirements, The Journal of Banking and Finance 23, 1031-1041.

Friedman, B. M.: 2013, The simple analytics of monetary policy: A postcrisis approach, National Bureau of Economic Research Working Paper Series. Working paper No. 18960.

Futagami, K. and Shibata, A.: 1998, Keeping one step ahead of the Joneses: Status, the distribution of wealth, and long run growth, Journal of Economic Behavior and Organization 36, 109-126. 
Gong, L. and Zou, H.-F.: 2001, Money, social status and capital accumulation in a cash-in-advance model, Journal of Money, Credit and Banking 33(2), 284-293.

Gupta, R.: 2008, Tax evasion and financial repression, Journal of Economics and Business 60, 517-535.

Gupta, R.: 2011, Currency substitution and financial repression, International Economic Journal 25(1), 47-61.

Gupta, R. and Ziramba, E.: 2009, Tax evasion and financial repression: a reconsideration using endogenous growth models, Journal of Economic Studies 36(6), 660-674.

Gupta, R. and Ziramba, E.: 2010, Openness, bureaucratic corruption and public policy in an endogenous growth model, International Business $\mathbb{E}$ Economics Research Journal 9(3), 147-158.

Haslag, J. H.: 1994, The effects of monetary policy in a model with reserve requirements. Working Paper 94-15, Federal Reserve Bank of Dallas.

Hosoya, K.: 2012, Non-separable utility, wealth effects, and economic growth in a monetary economy, Economics Bulletin 15(10), 1-7.

Jha, R. and Dang, T. N.: 2012, Inflation variability and the relationship between inflation and growth, Macroeconomics and Finance in Emerging Market Economies 5(1), 3-17.

Karnizova, L.: 2010, The spirit of capitalism and expectation-driven business cycles, Journal of Monetary Economics 57, 739-752.

Keynes, J. M.: 1920, The Economic Consequences of the Peace, New York: Harcourt Brace.

Kurz, M.: 1968, Optimal economic growth and wealth effects, International Economic Review 9, 348-357.

Mundell, R. A.: 1963, Inflation and real interest, Journal of Political Economy 71, 280-283.

Neanidis, K. C. and Savva, C. S.: 2013, Macroeconomic uncertainty, inflation and growth: Regime-dependent effects in the G7, Journal of Macroeconomics 35, 81-92. 
Primus, K.: 2013, Excess reserves, monetary policy and financial volatility. Discussion Paper No. 183, Centre for Growth and Business Cycle Research, Economic Studies, University of Manchester, Manchester, UK.

Rebelo, S.: 1991, Long-run policy analysis and long-run growth, Journal of Political Economy 9(9), 500-521.

Sidrauski, M.: 1967, Rational choice and patterns of growth in a monetary economy, American Economic Review Papers and Proceedings 57, 534544.

Sims, C. A.: 2012, Statistical modeling of monetary policy and its effects, American Economic Review 102(4), 1187.

Smith, A.: 1776, An Inquiry into the Nature and Causes of the Wealth of Nations, University Of Chicago Press. Reprinted, 1977.

Stockman, A. C.: 1981, Anticipated inflation and the capital stock in a cash-in-advance economy, Journal of Monetary Economics 8, 387-393.

Tobin, J.: 1965, Money and economic growth, Econometrica 33(4), 671-684.

Vaona, A. and Schiavo, S.: 2007, Nonparametric and semiparametric evidence on the long-run effects of inflation on growth, Economics Letters 94(3), 452-458.

Veblen, T.: 1899, The Theory of the Leisure Class: An Economic Study of Institutions, Allan and Unwin, London. Reprinted, Modern Library, New York, 1934.

Wang, P. and Yip, C. K.: 1992, Alternative approaches to money and growth, Journal of Money, Credit, and Banking 24(2), 553-562.

Weber, M.: 1905, The Protestant Ethic and "The Spirit of Capitalism", Roxbury Publishing Company. Translated by Stephen Kalberg (2002).

Zou, H.-F.: 1994, The spirit of capitalism and long-run growth, European Journal of Political Economy 10, 279-293.

Zou, H.-F.: 1998, The spirit of capitalism, social status, money, and accumulation, Journal of Economics 68(3), 219-233. 


\section{A Appendix}

Recall that the Hamiltonian of the consumer is stated in (4) as:

$$
H_{c}=\log (c)+\beta \log (d)+\lambda\left[r_{d} d+\tau-c-\pi m_{1}-\dot{d}\right]+q\left[m_{1}-c\right]
$$

and the resulting first-order conditions described in (5)-(7) is:

$$
\begin{aligned}
& \frac{d H_{c}}{d c}: \frac{1}{c}-\lambda-q=0 \\
& \frac{d H_{c}}{d m_{1}}:-\lambda \pi+q=\rho \lambda-\dot{\lambda} \\
& \frac{d H_{c}}{d d}: \frac{\beta}{d}+\lambda r_{d}=\rho \lambda-\dot{\lambda}
\end{aligned}
$$

For the banks, given that deposits and loans are one-period contracts, the solution that results directly from the zero profit condition due to competition, is:

$$
\Pi_{B}=\left[\left(i_{l}\right) l-\left(i_{d}\right) d\right]=0
$$

Imposing the two constraints in (9) and (10) and substituting into (8), we have:

$$
\begin{aligned}
\left(i_{l}\right)(1-\gamma) d & =\left(i_{d}\right) d \\
i_{l} & =\frac{i_{d}}{(1-\gamma)}
\end{aligned}
$$

which is the banks' solution, stated in (11). Based on the solution to the firm's static problem, given in (16), the net real deposit rate is obtained by substituting (16) into (11):

$$
\begin{aligned}
i_{l} & =\frac{i_{d}}{(1-\gamma)} \\
\left(i_{l}-\pi\right) & =\frac{i_{d}}{(1-\gamma)}-\pi \\
\left(i_{l}-\pi\right) & =\frac{i_{d}-\pi+\pi \gamma}{(1-\gamma)} \\
A(1-\gamma) & =r_{d}+\gamma \pi \\
r_{d} & =A(1-\gamma)-\gamma \pi
\end{aligned}
$$


For the balanced growth path (BGP) solutions, first calculate the endogenous inflation rate using (5)-(7):

$$
\begin{aligned}
-\lambda \pi+q & =\frac{\beta}{d}+\lambda r_{d} \\
\lambda \pi & =q-\frac{\beta}{d}-\lambda r_{d} \\
\lambda \pi & =\frac{1}{c}-\lambda-\frac{\beta}{d}-\lambda r_{d} \\
\lambda \pi & =\frac{1}{c}-\frac{\beta}{d}-\left(1+r_{d}\right) \lambda \\
\pi & =\frac{1}{c \lambda}-\frac{\beta}{d \lambda}-\left(1+r_{d}\right)
\end{aligned}
$$

then using (5) rearranged into (6), together with the inflation expression in (20), the evolution of the shadow price of real money balances is:

$$
\begin{aligned}
\rho \lambda-\dot{\lambda} & =-\lambda \pi+\frac{1}{c}-\lambda \\
\rho \lambda-\dot{\lambda} & =-\lambda\left(\frac{1}{c \lambda}-\frac{\beta}{d \lambda}-\left(1+r_{d}\right)\right)+\frac{1}{c}-\lambda \\
-\dot{\lambda} & =\frac{\beta}{d}+\left(r_{d}-\rho\right) \\
-\frac{\dot{\lambda}}{\lambda} & =\frac{\beta}{d \lambda}+\left(r_{d}-\rho\right)
\end{aligned}
$$

The evolution of real money balances, after substituting (20) into (19) and using the consumer's CIA constraint, $m_{1}=c$, becomes:

$$
\begin{aligned}
\frac{\dot{m}}{m} & =\mu-\pi \\
& =\mu-\frac{1}{c \lambda}+\frac{\beta}{d \lambda}+\left(1+r_{d}\right) \\
\frac{\dot{m}}{m} & =\mu-\frac{1}{m_{1} \lambda}+\frac{\beta}{d \lambda}+\left(1+r_{d}\right)
\end{aligned}
$$

and additionally, from the equilibrium condition for the goods market $c+i=$ $y$, and the binding CIA constraint $m_{1}=c$, we have:

$$
\frac{\dot{d}}{d}=A-\frac{m_{1}}{(1-\gamma) d}
$$


For a valid BGP solution, (24) must hold such that:

$$
-\frac{\dot{\lambda}}{\lambda}=\frac{\dot{m}}{m}=\frac{\dot{d}}{d}=g^{*}
$$

which presents a system of equations from which to solve for $g^{*}$. Using both the evolution of the shadow price and the evolution of the real money balances expressions:

$$
\begin{aligned}
g & =\frac{\beta}{d \lambda}+\left(r_{d}-\rho\right) \\
& =\mu-\frac{1}{m_{1} \lambda}+\frac{\beta}{d \lambda}+\left(1+r_{d}\right) \\
\mu+1+\rho & =\frac{1}{m_{1} \lambda} \\
\frac{1}{\lambda} & =(1+\mu+\rho) m_{1}
\end{aligned}
$$

and substituting the above into $g^{*}=-\frac{\dot{\lambda}}{\lambda}$ yields:

$$
\begin{aligned}
g & =\left(r_{d}-\rho\right)+\frac{\beta(1+\mu+\rho) m_{1}}{d} \\
\frac{m_{1}}{d} & =\frac{g-r_{d}+\rho}{\beta(1+\mu+\rho)}
\end{aligned}
$$

and hence, using the fact that $g^{*}=\frac{\dot{d}}{d}$ and $r_{d}=A(1-\gamma)-\gamma \pi$, an explicit expression for $g^{*}$ is derived:

$$
\begin{aligned}
g & =A-\left(\frac{g-r_{d}+\rho}{\beta(1+\mu+\rho)}\right) \frac{1}{1-\gamma} \\
g(1-\gamma) \beta(1+\mu+\rho) & =A(1-\gamma) \beta(1+\mu+\rho)-g+\left(r_{d}-\rho\right)
\end{aligned}
$$

and, in simplifying

$$
g^{*}=A-\frac{\rho+\gamma \mu}{(1-\gamma)[1+\beta(1+\mu+\rho)]}
$$

